\title{
Gait energy expenditure in children with Duchenne muscular dystrophy: case study
}

\author{
Gasto energético na marcha de crianças com distrofia muscular de Duchenne: estudo de caso \\ El gasto energético durante la marcha de los niños con distrofia muscular de Duchenne: \\ un estudio de caso
}

\author{
Mariana Angélica de Souza', Marília Ester Ferreira², Cyntia Rogean de Jesus Alves de Baptista ${ }^{3}$, \\ Ana Claudia Mattiello Sverzut ${ }^{4}$
}

\begin{abstract}
I This case study aimed to verify the model of Rose et al! as a feasible to assess energy expenditure in gait of children with Duchenne muscular dystrophy (DMD). Three DMD patients aged 6, 7 and 8 years old participated of this study. It was obtained weight, height, leg length measurement (LLM), resting and gait heart rate (HR) held on as 55-meter oval circuit performed during a two-minute test at each speed. Energy expenditure was calculated using the HR. It was performed a descriptive analysis (average) and these were compared, individually, to normative data. The average gait speed of these three patients was similar to the normative data for slow speed and lower considering comfortable and fast speed. The energy expenditure to slow speed of the patients 2 and 3 was similar to the normality, and lowest for patient 1; at comfortable speed, the energy expenditure obtained for all patients was similar; at fast speed, the patients 1 and 2 presented similar to normal values, but the patient 3 presented higher energy expenditure. It was concluded that the energy expenditure evaluation using HR was easily executed in the clinical practice and it can help therapeutic choices. For patient 3, an aerobic training could be indicated and for the others, they could keep the routine assessments.
\end{abstract}

Keywords I Muscular Dystrophy, Duchenne; Energy Metabolism; Gait; Child.
RESUMO I Este estudo de caso objetivou verificar se o modelo de Rose et al. é factível para avaliar o gasto energético na marcha em crianças com distrofia muscular de Duchenne (DMD). Participaram três crianças com DMD e idades de 6, 7 e 8 anos. Foram avaliados peso, altura, comprimento dos membros inferiores (CMMII), frequência cardíaca (FC) de repouso e de marcha realizada em circuito oval de 55 m durante um teste de 2 minutos em cada velocidade. 0 gasto energético foi calculado pela FC. Foi realizada análise descritiva dos dados (média) e estes foram comparados, individualmente, com dados normativos. A velocidade média ( Vm) da marcha dos três pacientes foi igual aos dados normativos na etapa velocidade lenta e menor nas etapas de velocidade confortável e rápida. O gasto energético na velocidade lenta dos pacientes 2 e 3 foi similar à normalidade, e menor para o paciente 1; na velocidade confortável, o gasto energético de todos os pacientes foi similar; na velocidade rápida, os pacientes 1 e 2 apresentaram valores similares ao normal, porém o paciente 3 teve maior gasto energético. Concluiu-se que a avaliação do gasto energético pela FC foi facilmente executada na clínica, podendo auxiliar na eleição de condutas. Para o paciente 3 poderia ser indicado um treinamento aeróbio e para os demais manter esse protocolo de avaliação nas visitas subsequentes.

Descritores I Distrofia Muscular de Duchenne; Metabolismo Energético; Marcha; Criança.

Study conducted at the Structure and Function of Skeletal Muscle - Laboratory of Scientific Research. Department of Biomechanics, Medicine and Rehabilitation of the Locomotor Apparatus and at the Center of Physical Education, Sports and Recreation of the Ribeirao Preto Medicine School of the Universidade de São Paulo (FMRP-USP) - Ribeirão Preto (SP), Brazil. ${ }^{1}$ Gradute Program in Rehabilitation and Functional Performance of the FMRP-USP - Ribeirão Preto (SP), Brazil. ${ }^{2}$ Laboratory of Scientific Research - Structure and Function of Skeletal Muscle of the FMRP-USP - Ribeirão Preto (SP), Brazil. ${ }^{3}$ Department of Biomechanics, Medicine and Rehabilitation of the Locomotor Apparatus of the FMRP-USP - Ribeirão Preto (SP), Brazil. ${ }^{4}$ Physical Therapy course of the Department of Biomechanics, Medicine and Rehabilitation of the Locomotor Apparatus of the FMRPUSP - Ribeirão Preto (SP), Brazil. 
RESUMEN I Este estudio de caso tuvo como objetivo verificar si el modelo de Rose et al es factible para evaluar el gasto de energía en la marcha de niños con distrofia muscular de Duchenne (DMD). Participaron tres niños con DMD con edades de 6, 7 y 8 años. Fueron evaluados peso, altura, longitud de las extremidades inferiores (LEI), frecuencia cardiaca (FC) en reposo y la marcha realizada en el circuito ovalado de 55 m durante un exámen de 2 minutos en cada velocidad. El gasto energético fue calculado por la FC. Se realizó un análisis descriptivo de los datos (media) y éstos fueron comparados de forma individual con los datos normativos. La velocidad media (VM) de la marcha de los tres pacientes fue igual a los datos normativos en la etapa velocidad lenta y menor en las etapas de velocidad confortable y rápida. El gasto de energía en la velocidad lenta de los pacientes 2 y 3 fue similar a la normalidad, y menor para el paciente 1; en la velocidad confortable, el gasto de energía de todos los pacientes fue similar; en la velocidad rápida, los pacientes 1 y 2 tuvieron valores similares a lo normal, pero el paciente 3 tuvo mayor gasto energético. Se concluyó que la evaluación del gasto energético por la FC se llevó a cabo fácilmente en la clínica, y pudo ayudar en la elección de conductas. Para el paciente 3 podría ser indicado un entrenamiento aeróbico y para los demás mantener ese protocolo de evaluación en las visitas siguientes.

Palabras clave I Distrofia muscular de Duchenne; Metabolismo Energético; Marcha; Niño.

\section{INTRODUCTION}

The Duchenne muscular dystrophy (DMD) is a genetic myopathy characterized by the progressive loss of muscle strength, from proximal to distal, first affecting the lower limbs and upper limbs later. This progressive muscle weakness cause postural and gait changes, leading the patient to loss of ambulation ${ }^{2-4}$. Thus, the rehabilitation of patients with DMD aims to slow the progress of deformities and to provide a better quality of life, especially for the maintenance of gait for as long as possible 4 .

Therefore, several are the instruments to assess the gait, which aim at understanding the biomechanical changes and also the energy cost to run it ${ }^{5}$. Seeking greater ease of measurement of energy expenditure during the gait of children, Rose et al. ${ }^{6}$ compared the energy expenditude index (EEI) by oxygen with the rate of energy expenditure by heart rate (HR) and concluded that, although both of them may be used in the evaluation of normal children and children with cerebral palsy, it is preferable to use the index obtained by $\mathrm{HR}$, given its ease of data acquisition.

The EEI, whose final result is expressed as number of heartbeats per meter walked ${ }^{5}$, is usually reported in children with cerebral palsy ${ }^{6-9}$, however restricted to works in patients with DMD. In these patients, the resting energy expenditure, measured by calorimetry, is the target of most studies ${ }^{10-13}$.

Taktak and Bowker ${ }^{14}$ compared the energy expenditure of gait in patients with DMD, between two types of orthoses. The EE was calculated by the HR at gait and at rest, and the average velocity $\left(\mathrm{V}_{\text {ave }}\right)$ of gait in a circuit of $8 \mathrm{~m}$. Other authors ${ }^{15}$ assessed energy expenditure in patients with DMD by the values of HR and $\mathrm{V}_{\text {ave }}$ obtained in the 6-minute walk test. However, no study has compared the energy expenditure during gait in patients with DMD with data from Rose et al. ${ }^{1}$.

Assessing the energy expenditure of gait by adopting HR may contribute to the monitoring of the disease's progression and, thus, favor the election of therapeutic approaches in patients with DMD. Thus, this case study aimed to verify whether the model of Rose et al. ${ }^{1}$ is feasible to be applied in clinic as an indirect parameter to indicate the energy expenditure of gait in children with DMD.

\section{METHODOLOGY}

\section{Sample}

Three patients, seen at the Infant Myopatbies's Ambulatory, Rebabilitation Center of Clinics Hospital of the Ribeirao Preto Medicine School, University of São Paulo (CER-HCFMRP-USP), participated in the study. The inclusion criteria were: confirmed diagnosis of DMD, to be over six years of age, independent community ambulation, similar functional score (up to two points of difference) in Dimension 1 (D1) of the Motor Function Measure (MFM) ${ }^{16}$ and the signing the Informed Consent Form (ICF) by the guardian. 
The exclusion criteria were: presence of cardiopulmonary diseases or cognitive insufficiency to understand the commands of the physical therapist.

The normative data on energy expenditure in gait by indirect analysis via HR for healthy children, proposed by Rose et al. ${ }^{1}$, were used I order to compare the results obtained with patients with DMD. Therefore, these data were broken down here as normative data of Rose et al. ${ }^{1}$.

\section{Procedures}

The clinical history of patients and the scores of MFM were obtained in the database of the Infant Myopathies's Ambulatory, Rebabilitation of the CER-HCFMRPUSP. The patients selected, according to the inclusion criteria, were invited to participate in the study and the assessments were scheduled for those whose guardians signed Informed Consent Form.

Patients were evaluated at the CEFER of the campus of Ribeirão Preto, USP. There were collected: weight, height, leg length measurement (LLM) and energy expenditure during gait. This case study has a crosssectional nature and each test (described below) was performed by the same examiner.

The weight was assessed on a Welmy ${ }^{\circledR}$ W200/5 electronic scale and the height on a stadiometer (Tonelli ${ }^{\circledR}$ ). These measurements were obtained with the barefoot child in a standing position. The LLM was obtained, by a measuring tape, with the child in the supine position, the distance between the anterior superior iliac spine and the medial malleolus. The body mass index (BMI) was calculated by dividing weight by height squared. The body composition was assessed by bioelectrical impedance (Biodynamics 450).

For the assessment of the energy expenditure in gait, a methodology similar to that described by Rose et al. ${ }^{1}$, was described, in which children ambulate in an oval circuit of $55 \mathrm{~m}$, in 3 steps, lasting 2 minutes each.

Initially, with the child in a seating position, it was collected the resting heart rate (RHR) through the HR monitor $\left(\operatorname{Polar}^{\circledR}\right)$. In the first stage, the child was asked to walk, through the circuit, at a comfortable speed, with the verbal command "walk normally, as you do every day". In the second stage, the child was asked to walk slowly: "walk very slowly". In the third one, they received the command: "walk as fast as you can, but without running”.

The walking heart rate (WHR) was collected in the last 30 seconds of each stage. Between the stages, children rested for 3 minutes, or until the HR would return to its resting value $+/-5$ beats/min.

The $V_{\text {ave }}$ of the gait and the EEI rate, at each stage, were calculated by the formulas $V_{\text {ave }}=d / t$ and $\mathrm{EE}=(\mathrm{HHR}-\mathrm{RHR}) / \mathrm{V}_{\text {ave }}$, respectively, since $\mathrm{d}$ is the total distance, in meters, and $t$ is the time duration of each step of the test ( $2 \mathrm{~min}$ ).

\section{Statistical analysis}

A descriptive analysis (average) of the data was performed. These were compared, individually, to the normative data (average and standard deviation) of Rose et al. (comprising typical children of 6-8 years of age) in the three stages of the test (slow, comfortable and fast speeds).

\section{RESULTS}

The measures of the anthropometric variables (weight, height, LLM), RHR and the percentage of fat increased with age. There was no difference between the length of the right and left lower limb. The score of MFM decreased with the advancing age (Table 1).

The Table 2 shows that the distance traveled, the resting and gait $H R$, the $V_{\text {ave }}$ and the energy expenditure increased according to the progression of the stage step in the test, for all the patients assessed, except for patient 3, who traveled the same distance and, thus, kept the $V_{\text {ave }}$ during the steps of slow and comfortable pace.

The older patients had lower scores of MFM and higher energy consumption (Tables 1 and 2).

Table 1. Characteristics of the sample in relation to the anthropometric variables, body composition and score of the measure of motor function

\begin{tabular}{|c|c|c|c|c|c|c|c|c|}
\hline & $\begin{array}{c}\text { Age } \\
\text { (years) }\end{array}$ & Weight (kg) & Height (cm) & BMI & $\begin{array}{l}\text { LLM } \\
(\mathrm{cm})\end{array}$ & $\begin{array}{c}\text { Fat-free mass/ } \\
\text { Fat mass (\%) }\end{array}$ & MFM* Score & $\begin{array}{l}\text { RHR } \\
\text { (bpm) }\end{array}$ \\
\hline 1 & 6 & 19.5 & 115 & 14.7 & 53 & $89.5 / 10.5$ & $71.7 \%$ (28) & 97 \\
\hline 2 & 7 & 19.2 & 120 & 13.3 & 59 & $88 / 12$ & $66.6 \%(26)$ & 98 \\
\hline 3 & 8 & 24.4 & 127 & 15.1 & 66.5 & $72.5 / 27.5$ & $61.5 \%(24)$ & 103 \\
\hline
\end{tabular}

BMI: body mass index; LLM: leg length measure; MFM: motor function measure; *Dimension 1 (raw score); bpm: beats per minute 
Table 2. Average velocity and calculation of the energy expenditure in comfortable, slow and fast speeds, for patients 1,2 and 3

\begin{tabular}{|c|c|c|c|c|c|c|c|c|c|}
\hline & \multicolumn{3}{|c|}{ Slow S. } & \multicolumn{3}{|c|}{ Comfortable S. } & \multicolumn{3}{|c|}{ Fast S. } \\
\hline & 1 & 2 & 3 & 1 & 2 & 3 & 1 & 2 & 3 \\
\hline $\mathrm{DW}(\mathrm{m})$ & 66.0 & 61.0 & 79.5 & 92.5 & 80.5 & 79.5 & 145.0 & 132.5 & 132.5 \\
\hline WHR (bpm) & 109 & 113 & 125 & 125 & 120 & 132 & 130 & 137 & 176 \\
\hline RHR (bpm) & 97 & 99 & 105 & 97 & 101 & 107 & 99 & 98 & 103 \\
\hline$V_{\text {ave }}(\mathrm{m} / \mathrm{min})$ & 33 & 30.5 & 39.75 & 46.25 & 40.25 & 39.75 & 72.5 & 66.25 & 66.25 \\
\hline EEI (beats/m) & 0.36 & 0.45 & 0.50 & 0.38 & 0.47 & 0.62 & 0.45 & 0.58 & 1.10 \\
\hline
\end{tabular}

S: speed; DW (m): distance walked in meters; WHR: walking heart rate; RHR: resting heart rate; bat $/ \mathrm{m}$ : batimentos por minuto; $V_{\text {ave }}$ ( $\mathrm{m} / \mathrm{min}$ ): average velocity in meters per minute; EEI (beats/m): energy expenditure index

Table 3. Comparison of the anthropometric variables between patients and the normative data of Rose et al.

\begin{tabular}{lcccc} 
& Normative data of & \multicolumn{3}{c}{ Patients } \\
\cline { 3 - 5 } & Rose et al. & 1 & 2 & 3 \\
Age (years) & $6-8$ & 6 & 7 & 8 \\
Weight (kg) & $28(5.7)^{*}$ & 19.5 & 19.2 & 24.4 \\
Height (cm) & $127(9.9)^{*}$ & 115 & 120 & 127 \\
LLM (cm) & $66(6.8)^{*}$ & 53 & 59 & 66.5 \\
RHR (bpm) & $83(10)^{*}$ & 97 & 98 & 103
\end{tabular}

*Mean (standard deviation); LLM: leg length measure; RHR (bpm): resting heart rate in beats per minute

Considering the averages and the standard deviations of healthy children ${ }^{1}$, the weight and the LLM of patients 1 and 2 were lower, however, the values of patient 3 were normal. As for height, patient 1 was the only one who got a result lower than the ones of the control group, patients 2 and 3 had similar results to the healthy group studied by Rose et al. ${ }^{1}$.The RHR of the three patients was higher than that obtained in the healthy group studied by Rose et al. ${ }^{1}$. The height, the length of the lower limbs and the RHR increased with age (Table 3).

Table 4 shows the comparison between the average speeds and the energy expenditure in patients 1,2 and 3 and the normative data of Rose et al. ${ }^{1}$.

All patients had $V_{\text {ave }}$ within the interval (average and standard deviation) of the data presented by Rose et al. ${ }^{1}$, in the slow speed stage, and lower $\mathrm{V}_{\text {ave }}$ in comfortable and fast speeds.

The energy expenditure of patients, when compared to normality standards ${ }^{1}$, behaved differently according to the gait speed.

Patient 1 had an energy expenditure within the range (average and standard deviation) of the normative data of Rose et al. ${ }^{1}$, at comfortable and fast speeds, and lower energy expenditure interval (average and standard deviation) in the control group at slow speed.

Patient 2 had energy expenditure within the interval range (average and standard deviation) of the normative data of Rose et al. ${ }^{1}$ at the three speeds (slow, comfortable and fast).
Patient 3 had energy expenditure within the range (mean and standard deviation) of the normative data of Rose et al. ${ }^{1}$, at slow and comfortable speeds, and higher energy expenditure in fast speed.

Figure 1 shows the values for the energy expenditure of patients with DMD in three speeds (slow, comfortable and fast). There was an increase in energy expenditure with age progression. It is observed that the energy expenditure of patients 1 and 2 similarly increased according to the speed progression. However, the increased energy expenditure of patient 3 was more pronounced, especially at comfortable to fast speed.

\section{DISCUSSION}

Given the scarcity of studies on energy expenditure of gait in patients with DMD, this study aimed to verify whether the model of Rose et al. ${ }^{1}$ is feasible in order to assess the energy expenditure during gait in children with DMD.

As in the study by Rose et al. ${ }^{1}$, anthropometric data were obtained, and the values of height and weight of the evaluated patients were similar to the findings of other authors ${ }^{14,17}$. Based on the normative data of Rose et al. ${ }^{1}$, the weight and length of the lower limbs of patients 1 and 2 were lower, and of patient 3 were similar. As for the height, only patient 1 had an inferior result, patients 2 and 3 had similar results. As opposed to that, other authors have shown that DMD patients have lower height and weight than healthy children ${ }^{2}$.

The progression of DMD leads to a functional decline. In this sense, the MFM is the ideal monitoring tool, and its Portuguese version features high reliability ${ }^{16}$. According to the literature ${ }^{18}$, the score of the MFM decreased with age. In this case study, an increased energy expenditure with functional decline of the patients analyzed (scores of patients 1, 2 and 3 differed by 2 points among themselves) may be observed. These data may suggest an inverse relationship between the score of the 
Table 4. Comparison of the average velocity and the energy expenditure between patients and the normative data of Rose et al!

\begin{tabular}{lcccccc} 
& \multicolumn{3}{c}{} & \multicolumn{3}{c}{ EEl (beats/m) } \\
\cline { 2 - 6 } & Slow & Comfortable & Fast & Slow & Comfortable & Fast \\
Normative data of & $35(9.9)^{*}$ & $65(8.4)^{*}$ & $93(13.1)^{*}$ & $0.75(0.36)^{*}$ & $0.48(0.15)^{*}$ & $0.60(0.20)^{*}$ \\
Rose et al! & 33 & 46.25 & 72.50 & 0.36 & 0.38 & 0.45 \\
Patient 1 & 30.50 & 40.25 & 66.25 & 0.45 & 0.47 & 0.58 \\
Patient 2 & 39.75 & 39.75 & 66.25 & 0.50 & 0.62 & 1.10
\end{tabular}

$V_{\text {ave }}(\mathrm{m} / \mathrm{min})$ : average velocity in meters per minute; EEl (beats $\left./ \mathrm{m}\right)$ : rate of energy expenditure in beats per meter; *Mean (standard deviation)

MFM and the energy expenditure, i.e., higher scores on MFM, lower energy expenditure during gait.

For the calculation of the energy expenditure, the heart rates and the gait $V_{\text {ave }}$ were considered. In accordance with the literature ${ }^{19}$, the RHR of the evaluated patients was higher than in the healthy group studied by Rose et al. ${ }^{1}$. This result may be explained by the autonomic nervous system dysfunction, which occurs precociously in patients with DMD, causing decreased parasympathetic activity and/or increased sympathetic activity with the progression of the disease ${ }^{20}$. The decrease in the comfortable $V_{\text {ave }}$ with the advancing age and the lowest speeds (comfortable and fast), when compared to healthy children, may be explained by changes in the gait of patients with DMD with the progression of the disease. In another study ${ }^{2}$, there was no difference between the $\mathrm{V}_{\text {ave }}$ of gait in patients with DMD and the control group. As opposed to that, Gaudreault et al. ${ }^{21}$ showed that the walking speed of patients was lower than the control group, and that the usual $V_{\text {ave }}$ in patients with DMD does not differ from the slow speed of the control group.

The total energy expenditure encompasses the energy expenditure while at rest and its spend in activity. In DMD patients, the resting energy expenditure is often reported. Some authors report that, in these patients, the resting energy expenditure is lower than in the control group and emphasize the need for longitudinal studies, in order to understand these changes with the progression of the disease $\mathrm{e}^{10}$. On the contrary, to other authors ${ }^{12}$, the resting energy expenditure is higher in patients with DMD than in healthy children, and yet, this expenditure is lower in obese rather than in nonobese patients with DMD. In this sense, it is emphasized that the analysis of energy expenditure should be related to the body composition analysis.

In healthy children, there is a positive correlation between fat and energy expenditure, and this is inversely proportional to the lean body mass ${ }^{22}$. In this study, the increase in energy expenditure with age is consistent with the accumulation of body fat and the loss of lean mass, characteristic aspects of the progression of the

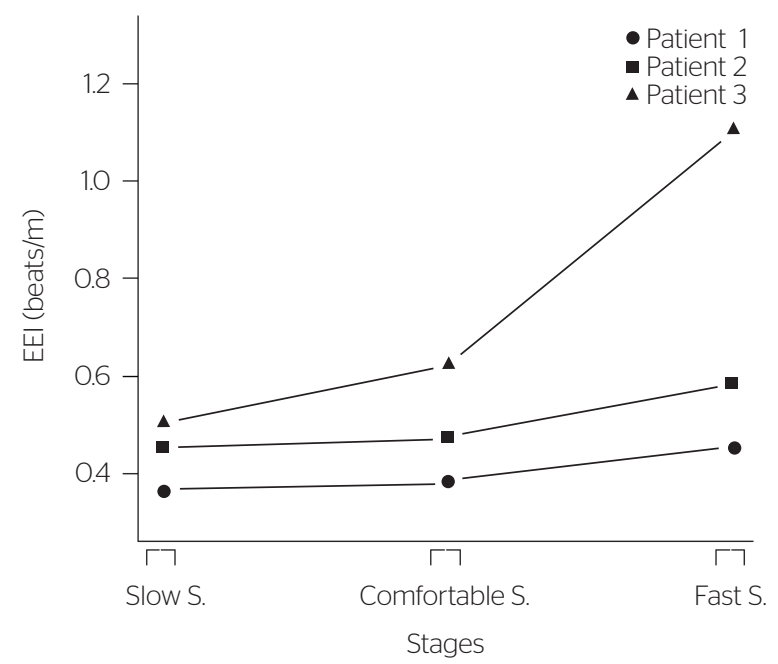

S: speed; EEl: energy expenditure index

Figure 1. Energy expenditure of patients 1, 2 and 3 in slow, comfortable and fast speeds

$\mathrm{DMD}^{17}$. Still, only 3 patients showed higher energy expenditure, when compared to the normative data from Rose et al. ${ }^{1}$, which seems to be justified due to a higher percentage of fat than in other evaluated patients.

Three major factors limit the discussion of the results obtained here ${ }^{1}$ : the lack of studies on energy expenditure during gait in patients with $\mathrm{DMD}^{2}$, the methodological variety of studies on resting energy expenditure and the number of subjects analyzed here ${ }^{3}$. For this reason, generalizations would be improper, limited, thus, to the proposition of interventions only to the participants patients.

From these results, further studies must be conducted in a larger number of patients. An inverse relationship between the score of the MFM and the energy expenditure is hypothesized, assessed by the HR, which will be able to be minimized by the early indication of therapeutic aerobic training.

\section{CONCLUSION}

In the three children with DMD who participated in this study, the assessment of energy expenditure of 
gait by adopting HR and pairing it with the data from healthy children ${ }^{1}$ were easily implemented in the clinic. The model used by Rose et al. ${ }^{1}$ seems to indicate the energy expenditure of gait in children with DMD and proved to be a tool which may assist the therapist in the election of their conduct. For patient 3, the data obtained in this study suggest that the development of the aerobic training may minimize the deleterious response in the cardiorespiratory system which tracks the progression of the DMD. The remaining patients could be given only routine assessments to measure energy expenditure of walking at different speeds. Still, other patients with different scores of MFM should be analyzed, following the proposed methodology, in order to increase the conclusions listed here.

\section{ACKNOWLEDGEMENTS}

We are grateful to the CEFER of USP (campus of Ribeirão Preto), to Prof. Dr. Hugo Celso Dutra de Souza and to the laboratory technician Ana Paula Manfio.

\section{REFERENCES}

1. Rose J, Gamble JG, Lee J, Lee R, Haskell WL. The energy expenditure index: a method to quantitate and compare walking energy expenditure for children and adolescents. J Pediatr Orthop. 1991;11(5):571-8.

2. Doglio L, Pavan E, Pernigotti I, Petralia P, Frigo C, Minetti C. Early signs of gait deviation in Duchenne muscular dystrophy. Eur J Phys Rehabil Med. 2011:47(4):587-94.

3. Humbertclaude V, Hamroun D, Bezzou K, Bérard C, Boespflug-Tanguy $\mathrm{O}$, Bommelaer $\mathrm{C}$, et al. Motor and respiratory heterogeneity in Duchenne patients: Implication for clinical trials. Eur J Paediatr Neurol. 2012;16(2):149-60.

4. Vuillerot C, Girardot F, Payan C, Fermanian J, Iwaz J, De Lattre C, et al. Monitoring changes and predicting loss of ambulation in Duchenne muscular dystrophy with the Motor Function Measure. Dev Med Child Neurol. 2010;52(1):60-5

5. Tanaka MS, Luppi A, Morya E, Fávero FM, Fontes SV, Oliveira ASB. Principais instrumentos para a análise da marcha de pacientes com distrofia muscular de Duchenne. Rev Neurocienc.2007:15(2):153-9.

6. Rose J, Gamble JG, Burgos A, Medeiros J, Haskell WL. Energy expenditure index of walking for normal children and for children with cerebral palsy. Dev Med Child Neurol. 1990;32(4):333-40.
7. Bratteby Tollerz LU, Olsson RM, Forslund AH, Norrlin SE. Reliability of energy cost calculations in children with cerebral palsy, cystic fibrosis and healthy controls. Acta Paediatr. 2011;00(12):1616-20.

8. Konop KA, Strifling KM, Wang M, Cao K, Eastwood D, Jackson S, et al. Upper extremity kinetics and energy expenditure during walkerassisted gait in children with cerebral palsy. Acta Orthop Traumatol Turc, 2009:43(2):156-64. [Turkish].

9. IJzerman MJ, Nene AV. Feasibility of the physiological cost index as an outcome measure for the assessment of energy expenditure during walking. Arch Phys Med Rehabil. 2002;83(12):1777-82.

10. Shimizu-Fujiwara M, Komaki H, Nakagawa E, Mori-Yoshimura M, Oya Y. Fujisaki T, et al. Decreased resting energy expenditure in patients with Duchenne muscular dystrophy. Brain Dev. 2012;34(3):206-12.

11. Elliott SA, Davidson ZE, Davies PS, Truby H. Predicting resting energy expenditure in boys with Duchenne muscular dystrophy. Eur J Paediatr Neurol. 2012:16(6):631-5.

12. Zanardi MC, Tagliabue A, Orcesi S, Berardinelli A, Uggetti C, Pichiecchio A. Body composition and energy expenditure in Duchenne muscular dystrophy. Eur J Clin Nutr. 2003;57(2):273-8.

13. Gonzalez-Bermejo J, Lofaso F, Falaize L, Lejaille M, Raphaël JC, Similowski T, et al. Resting energy expenditure in Duchenne patients using home mechanical ventilation. Eur Respir J. 2005;25(4):682-7.

14. Taktak DM, Bowker P. Lightweight, modular knee-ankle-foot orthosis for duchenne muscular dystrophy: design, development, and evaluation. Arch Phys Med Rehabil. 1995;76(12):1156-62.

15. McDonald CM, Henricson EK, Abresch RT, Florence J, Eagle M, Gappmaier E, et al. The 6-minute walk test and other clinical endpoints in Duchenne mucular Dystrophy: reliability, concurrent validity, and minimal clinically important differences from a multicenter study. Muscle Nerve. 2013;48(3):357-68.

16. Iwabe C, Miranda-Pfeilsticker BH, Nucci A. Medida da função motora: versão da escala para o português e estudo de confiabilidade. Rev Bras Fisioter. 2008;12(5):417-24.

17. Caromano FA, Tanaka C, João SMA, Kamisaki AP, Yano KC, Ide MR. Correlação da massa e porcentagem de gordura com a idade na Distrofia Muscular de Duchenne. Fisioter Mov. 2010;23(2):221-7.

18. Fischmann A, Hafner P, Gloor M, Schmid M, Klein A, Pohlman U, et al. Quantitative MRI and loss of free ambulation in Duchenne muscular dystrophy. J Neurol. 2013;260(4):969-74.

19. Thomas TO, Morgan TM, Burnette WB, Markham LW. Correlation of heart rate and cardiac dysfunction in Duchenne muscular dystrophy. Pediatr Cardiol. 2012;33(7):1175-9.

20. Yotsukura M, Fujii K, Katayama A, Tomono Y, Ando H, Sakata K, et al. Nine-year follow-up study of heart rate variability in patients with Duchenne-type progressive muscular dystrophy. Am Heart J. 1998:136(2):289-96

21. Gaudreault N, Gravel D, Nadeau S, Houde S, Gagnon D. Gait patterns comparison of children with Duchenne muscular dystrophy to those of control subjects considering the effect of gait velocity. Gait Posture. 2010;32(3):342-7.

22. Goran MI, Nagy TR, Gower BA, Mazariegos M, Solomons N, Hood V, et al. Influence of sex, seasonality, ethnicity, and geographic location on the components of total energy expenditure in young children: implications for energy requirements. Am J Clin Nutr. 1998;68:675-82. 